\title{
sciendo
}

DOI 10.2478/sbe-2019-0012

SBE no. 14(1) 2019

\section{EFFECT OF CORPORATE GOVERNANCE RULES ON VOLUNTARY DISCLOSURE IN JORDANIAN CORPORATIONS LISTED WITH THE AMMAN STOCK EXCHANGE (ASE): (AN EMPIRICAL STUDY)}

\author{
MUNTHER AI-Nimer \\ Amman, Jordan
}

\begin{abstract}
:
This paper aims to examine the impact of corporate governance (CG) rules using several variables-size of the board of directors, size of the audit committee, family ownership ratio, and their impact on the level of the voluntary disclosure of companies listed with Amman Stock Exchange (ASE). The study was conducted based on the annual reports of the first market that include 55 firms. Content analysis was applied to collect the required data from several sectors (financial, insurance, services, and industrial sectors) from 2016 to 2017. The results indicate a negative association among family ownership ratio, size of the audit committee, and voluntary disclosure level. However, the study shows that the size of the board of directors has a significant positive relationship with the level of voluntary disclosure. Furthermore, the results show that CG rules (size of the board of directors, size of the audit committee, and family ownership ratio) have a significant positive relationship with the voluntary disclosure level of the companies listed with ASE. In the borderline market environment, the study contributes to a theoretical understanding of the corporate governance of voluntary disclosure and the relationship between corporate governance mechanisms and voluntary disclosure. The outcomes provide empirical support for the theoretical notion that effective corporate governance plays an important role in increasing the extent of voluntary disclosure.
\end{abstract}

Key words: Corporate Governance (CG) rules, Voluntary Disclosure, Amman Stock Exchange (ASE)

\section{Introduction}

Corporate governance (CG) is an effective tool that encourages investment in the stock market, which affects stock prices because the securities markets need plenty of elements to raise their efficiency by providing all the information needed by investors in a 
timely manner and at an appropriate cost (Premuroso and Bhattacharya, 2008; Cong and Freedman, 2011).

The available information necessary for investors represents the minimum requirements for disclosure and transparency in the modern business environment (Hodgdon and Hughes, 2016). Therefore, several studies explored the levels of CG that are applied by companies and determined the factors that influence the application of such levels such as those of Ortas et al. (2015), Qiu et al. (2016), Ji et al. (2015), and Othman et al. (2014).

As such, the accounting and non-accounting information provided by the company to the stakeholders is the window considered by the parties not only for the performance and financial position, but also for other nonfinancial information about the company such as management information, key owners, company plans, policies, activities, and other information to identify the company and make appropriate decisions to deal with it.

Several studies attempted to explore the level of voluntary disclosure, for instance, those of Abubakar and Syamarlah (2014), Narendra (2014), Samaha et al. (2012), and Mishari et al. (2017). Some of them examined the factors that influence the level of discourse of voluntary items, namely that of Akhtaruddin and Haron (2010) and Huafang and Jianguo (2007). Other studies attempted to examine the effect of CG on the level of voluntary disclosure, for instance, those of Poh-Ling and Grantley (2013), Lakhal (2005), Ehtazaz et al. (2016), Elmagrhi et al. (2016), Habbash (2016), Alhazaimeh et al. (2014), and Gisbert and Navallas (2013).

Accordingly, the present study aims to measure the degree of application of governance rules and thus measures the voluntary disclosure level. The study measures the effect of the application of the governance rules on the voluntary disclosure level in public shareholding companies listed with the ASE.

\subsection{Statement of the problem}

The problem of the study stems from the extent of the application of the governance rules and its impact on the voluntary disclosure level, which is positively reflected on financial statement beneficiaries. The study seeks to answer the main question:

- What is the impact of the application of the governance rules on the voluntary disclosure level of public shareholding companies listed with the ASE?

From the said question, the following problems emerge:

1. Is there a relationship between the family ownership ratio and the voluntary disclosure level of public shareholding companies listed with the ASE?

2. Does the size of the audit committee affect the voluntary disclosure level of public shareholding companies listed with the ASE?

3. Does the size of the board of directors affect the disclosure level of the public shareholding companies listed with the ASE?

\subsection{Significance of the study}

This study draws on the importance of applying governance rules in public shareholding companies listed with the ASE and benefiting from them in the development 
of accounting practices by highlighting their impact on voluntary disclosure level. The level will be measured through a set of disclosure items that measure three major groups, i.e., financial information, nonfinancial information, strategic information (Meek et al., 1995) and their combined statement and respective impact.

\section{Study Hypothesis}

In light of the study problem and its objectives, the following main hypothesis was formulated, which will be tested to draw conclusions and make appropriate recommendations:

Main hypothesis: The application of governance rules has no impact on the voluntary disclosure level of public shareholding companies listed with the ASE.

In line with this, the following subhypotheses were derived:

First subhypothesis: The family ownership ratio has no statistically significant effect on the voluntary disclosure level of public shareholding companies listed with the ASE.

Second subhypothesis: The size of the board of directors has no statistically significant effect on the level of voluntary disclosure of public shareholding companies listed with the ASE.

Third subhypothesis: The size of the audit committee has no statistically significant effect on the voluntary disclosure level of public shareholding companies listed with the ASE.

\section{Study Methodology}

The study relied on a quantitative analytical approach to what is classified as methodological procedures that help in formulating analytical topics, finding the main sources, criticizing them, constructing facts, and drafting generalizations to reach the principles and explanations of causation. This type of approach suggests criteria for judging the credibility of a study related to public policy, 2005, p. 283) to achieve the goals of studying the independent variables and showing their effect on the dependent variable.

\subsection{Study community and sample}

The study community consists of public shareholding companies listed with the ASE, and 55 companies of which were classified as first markets as of the end of 2016. Companies from different sectors (banking, insurance, services, and industrial sectors) are included so that the researcher can study the Amman Financial Market and each sector separately. The 55 listed companies in the ASE were surveyed from 2016 to 2017.

\subsection{Methods of data analysis}

To achieve the objectives of the study, simple and multiple regression coefficients are used in this study to test the stated hypotheses and determine the effect of the independent variables on the dependent variable. In addition, descriptive statistical methods are used for all variables to support the study results so that that the hypotheses can be rejected or accepted. The researcher developed said tools using the Statistical Analysis Program (SPSS) to measure the study variables of governance and to show their impact on the dependent variable of voluntary disclosure. 


\section{Literature Review}

Several studies examined corporate voluntary disclosure practices. For instance, Al Mamun and Kamardin (2014) explored the corporate voluntary disclosure practices of listed banks of Bangladesh, an emerging economy. Their findings showed that the extent of voluntary disclosure significantly improved from 2005 to 2008 . However, the level of disclosure items related to $C G$ and risk management are lower than other disclosure categories.

Abdullah et al. (2015) investigated the determinants of voluntary CG disclosure practices of 67 Islamic banks in the Southeast Asian and Gulf Cooperation Council regions. The study indicated that the mean level of voluntary governance disclosure is less than $40 \%$. In addition, the study provided evidence that stronger CG is associated with a higher level of voluntary CG disclosure. Finally, it indicated that the other factors that influenced voluntary governance disclosures were the size of Islamic banks, the degree of political and civil repression, and the legal system.

In terms of examining the relationship between CG and social responsibility information disclosure, Liu and Zhang (2017) found that there is a declining level of social responsibility information disclosure by listed enterprises in heavy-pollution industries. In addition, different CG factors affect the social responsibility information disclosure of listed companies in heavy-pollution industries to a certain extent. Furthermore, Liu and Zhang (2017) indicated that social responsibility information disclosure is not beneficial for the short-term profit of an enterprise, but it can increase its long-term value. In general, a high level of CG is favorable for legitimacy management, as well as social responsibility information disclosure.

Caspar Rose (2016) investigated the degree of adherence of a Danish firm to the Danish Code of CG and analyzed if a higher degree of comply or explain disclosure is related to firm performance. The analysis showed that there is a positive link between ROE/ROA and Danish firm's overall CG comply or explain disclosure scores. In particular, this is also the case when this level is increased within the following two categories: board composition and remuneration policy; on the other hand, there is no impact on performance when compliance is improved based on the recommendations on risk management and internal controls. Similarly, Ararat et al. (2017) examined the effect of CG on firm value and profitability and indicated that CG will have a positive effect on firm value, particularly profitability. In addition, Dai et al. (2016) indicated that well-governed firms restrict informed insiders from trading mainly to reduce legal risks, and their study results highlighted how better-governed firms are able to restrict insiders from exploiting private information. Laura et al. (2017) contradicted the socioemotional wealth perspective that family control and influence increase CSR disclosure.

The relationship between governance and firm performance is an increasing function of dispersed ownership, and the value addition of good governance is not necessarily maintained at high ownership concentration levels. Furthermore, such a relationship reaches its highest level when the government or local corporations are the firm's major shareholders (Abdallah and Ismail, 2017).

Arcay and Vázquez (2005) examined the relationships among corporate characteristics, the governance structure of the firm, and its disclosure policy. The study 
revealed that the size of a firm, along with some mechanisms of CG, such as the proportion of independents on the board, the appointment of an audit committee, and directors' shareholdings and stock option plans, is positively related to voluntary disclosure. In addition, governance practices are significantly influenced by cross-listings and by the ownership structure of the firm.

Schoenfeld (2017) indicated that voluntary disclosure increases with the level of ownership assumed by index funds, and this increase in disclosure is associated with increased stock liquidity, which implies that voluntary disclosure increases stock liquidity. Grigoris Giannarakis (2014) indicated that the size of a company, the board's commitment to CSR, and profitability positively associated with the extent of CSR disclosure, while financial leverage is negatively related with the extent of CSR disclosure.

Ho and Wong (2001) indicated that the existence of an audit committee is significantly and positively related to the extent of voluntary disclosure, while the percentage of family members on the board is negatively related to the extent of voluntary disclosure.

Razali and Arshad (2014) provided evidence that the effectiveness of CG structure reduces the likelihood of fraudulent financial reporting. These results indicate that effective CG structure is paramount in enhancing the credibility of financial reporting.

Briano-Turrent and Rodríguez-Ariza (2016) provided strong empirical evidence that board independence, ownership concentration, and stakeholder orientation positively affect CG ratings, while the size of the board decreases CG compliance in Latin American countries.

\section{Results}

This part presents the descriptive analysis of the study variables by sector.

Table 1 shows the descriptive analysis of the study variables. As shown in the table, the services sector is the sector with the highest voluntary disclosure at a mean of 20.38 and with the highest value at 23 , while the insurance sector has the lowest voluntary disclosure at a mean of 14.333. In terms of family ownership ratio, the insurance sector has the highest mean at 0.14 , while the industrial sector has the lowest at 0.03 . In terms of size of the council management, the banking sector is the largest, whereas the insurance sector is the smallest. In terms of size of the audit committee, the banking sector is the largest, whereas the industrial sector is the smallest.

In addition to the descriptive analysis of the variables of the independent study, a descriptive analysis of the study variable (voluntary disclosure level) was conducted according to the optional disclosure classifications. Eight classifications were drawn, as shown in the following table. 
Studies in Business and Economics no. 14(1)/2019

Table 1. Descriptive Analysis of the Study Variables

\begin{tabular}{|c|c|c|c|c|c|}
\hline $\begin{array}{c}\text { Audit } \\
\text { Committee } \\
\text { Size }\end{array}$ & Board Size & $\begin{array}{c}\text { Ownership } \\
\text { Ratio }\end{array}$ & $\begin{array}{c}\text { Voluntary } \\
\text { Disclosure } \\
\text { Level }\end{array}$ & & Sector \\
\hline 2.5770 & 10.4620 & 0.0500 & 19.923 & Mean & \multirow{4}{*}{ Banking } \\
\hline 1.9220 & 1.7260 & 0.0760 & 3.4870 & $\begin{array}{l}\text { Standard } \\
\text { deviation }\end{array}$ & \\
\hline 6.0000 & 13.0000 & 0.0800 & 23.0000 & Highest value & \\
\hline 0.0000 & 6.0000 & 0.0000 & 7.0000 & Lowest value & \\
\hline 2.0000 & 5.5000 & 0.1400 & 14.3330 & Mean & \multirow{4}{*}{ Insurance } \\
\hline 1.5500 & 4.3240 & 0.1190 & 5.7155 & $\begin{array}{l}\text { Standard } \\
\text { deviation }\end{array}$ & \\
\hline 3.0000 & 9.0000 & 0.2000 & 19.0000 & Highest value & \\
\hline 0.0000 & 0.0000 & 0.0000 & 7.0000 & Lowest value & \\
\hline 0.2857 & 8.6430 & 0.0600 & 20.3800 & Mean & \multirow{4}{*}{ Services } \\
\hline 0.8913 & 2.7390 & 0.1240 & 2.0360 & $\begin{array}{l}\text { Standard } \\
\text { deviation }\end{array}$ & \\
\hline 3.0000 & 14.0000 & 0.0900 & 23.0000 & Highest value & \\
\hline 0.0000 & 5.0000 & 0.0000 & 14.0000 & Lowest value & \\
\hline 0.2220 & 7.3056 & 0.0300 & 19.3890 & Mean & \multirow{4}{*}{ Industrial } \\
\hline 0.9290 & 2.9940 & 0.0880 & 3.2890 & $\begin{array}{l}\text { Standard } \\
\text { deviation }\end{array}$ & \\
\hline 4.0000 & 13.0000 & 0.4000 & 23.0000 & Highest value & \\
\hline 0.0000 & 0.0000 & 0.0000 & 9.0000 & Lowest value & \\
\hline 0.9000 & 8.4640 & 0.0500 & 19.4455 & Mean & \multirow{4}{*}{ Total } \\
\hline 1.6020 & 3.0220 & 0.1050 & 3.3330 & $\begin{array}{l}\text { Standard } \\
\text { deviation }\end{array}$ & \\
\hline 6.0000 & 14.0000 & 0.0700 & 23.0000 & Highest value & \\
\hline 0.0000 & 0.0000 & 0.0000 & 7.0000 & Lowest value & \\
\hline
\end{tabular}

Table 2. Voluntary Disclosure Level

\begin{tabular}{|c|c|c|c|c|c|}
\hline Items & $\begin{array}{l}\text { Lowest Item to Be } \\
\text { Disclosed }\end{array}$ & $\begin{array}{l}\text { Most Widely } \\
\text { Disclosed Item }\end{array}$ & $\begin{array}{l}\text { Standard } \\
\text { Deviation }\end{array}$ & Mean & $\begin{array}{c}\text { Disclosure } \\
\text { Ratio of } \\
\text { the Total }\end{array}$ \\
\hline $\begin{array}{l}\text { General } \\
\text { information of } \\
\text { the company }\end{array}$ & $\begin{array}{l}\text { Statement of the } \\
\text { company's strategy } \\
\text { and objectives by } \\
\text { applying } 0 \%\end{array}$ & $\begin{array}{l}\text { Description of the } \\
\text { company's history } \\
\text { by applying } 100 \%\end{array}$ & 0.13987 & 0.4303 & $11.5 \%$ \\
\hline $\begin{array}{l}\text { CG } \\
\text { administrative } \\
\text { body }\end{array}$ & $\begin{array}{l}\text { Minutes of the } \\
\text { ordinary } \\
\text { extraordinary general } \\
\text { assembly meeting by } \\
\text { applying a rate of } 0 \%\end{array}$ & $\begin{array}{l}\text { List of directors by } \\
96 \%\end{array}$ & 0.18223 & 0.7909 & $21.1 \%$ \\
\hline $\begin{array}{l}\text { Financial } \\
\text { information }\end{array}$ & $\begin{array}{l}\text { Policies for the } \\
\text { provision of intangible } \\
\text { assets by applying } \\
35 \%\end{array}$ & $\begin{array}{l}\text { Main source of } \\
\text { revenue and } \\
\text { revenue by applying } \\
96 \%\end{array}$ & 0.19003 & 0.7200 & $19.2 \%$ \\
\hline
\end{tabular}


Studies in Business and Economics no. 14(1)/2019

\begin{tabular}{|c|c|c|c|c|c|}
\hline $\begin{array}{l}\text { Financial audit } \\
\text { information }\end{array}$ & $\begin{array}{l}\text { Net asset value per } \\
\text { share applying } 0 \%\end{array}$ & Dividends & 0.13546 & 0.3750 & $10.0 \%$ \\
\hline $\begin{array}{l}\text { Employees } \\
\text { information }\end{array}$ & $\begin{array}{l}\text { Social affairs / staff } \\
\text { welfare information } \\
\text { applying } 0 \%\end{array}$ & $\begin{array}{l}\text { For the period by } \\
\text { applying } 77 \%\end{array}$ & 0.19070 & 0.4600 & $12.3 \%$ \\
\hline $\begin{array}{l}\text { Future } \\
\text { forecasting } \\
\text { information }\end{array}$ & $\begin{array}{l}\text { Predicting future cash } \\
\text { flow qualitatively by } \\
\text { applying } 0 \%\end{array}$ & Total number & 0.04701 & 0.0091 & $0.2 \%$ \\
\hline $\begin{array}{l}\text { Social } \\
\text { Responsibility } \\
\text { Information }\end{array}$ & $\begin{array}{l}\text { Safety procedures } \\
\text { information by } \\
\text { applying } 2 \%\end{array}$ & $\begin{array}{l}\text { The company's } \\
\text { employees applied } \\
85 \%\end{array}$ & 0.30690 & 0.4667 & $12.5 \%$ \\
\hline $\begin{array}{l}\text { Graphic } \\
\text { Information }\end{array}$ & $\begin{array}{l}\text { Graphic } \\
\text { representation } \\
\text { nonfinancial } \\
\text { information } \\
\text { applying } 23 \%\end{array}$ & Share prediction & 0.34198 & 0.4955 & $13.2 \%$ \\
\hline
\end{tabular}

Table 2 presents eight classifications of optional disclosure and their respective accounting mean and standard deviation. As each classification includes several items, the highest and the lowest items for each classification have been identified. It is worth noting that the classification of companies that represents the highest percentage of the total classifications. The mean is 0.79 , and the standard deviation is 0.18 , which explains the difference between the percentages of the most disclosed item for this classification, which is $96 \%$, represented by the list of directors. The least disclosed item is the minutes of the meeting of the body at $0 \%$. On the other hand, it is clear from the table that the lowest percentage of the total classifications represented the classification of future forecasting information as it reached $0.2 \%$ of the total classifications. Was disclosed for this rating, which is $4 \%$ represented by the market share forecasting item - qualitative.

A test was conducted to verify whether there is no high correlation problem between study variables.

The correlation problem arises when the variables in the regression model are highly correlated. The correlation problem in the regression model affects the coefficients of the explanatory variables and creates an unrealistic increase in the correlation coefficient between the variables of the study. Zu'bi and Al-Talafah (2003) pointed out that this problem is present if the Pearson coefficient is equal to or greater than $80 \%$. To determine if there is no high association problem between the study variables, the following Pearson correlation matrix was used.

Table 3. Correlation Test between Variables

\begin{tabular}{|l|l|l|l|}
\hline $\begin{array}{l}\text { Audit Committee } \\
\text { Size }\end{array}$ & Board Size & Family Ownership Ratio & Variable \\
\hline & & 1.000 & Family ownership ratio \\
\hline $\mathbf{1}$ & 1 & 0.105 & Size of the board \\
\hline & 0.267 & 0.035 & $\begin{array}{l}\text { Size of the audit } \\
\text { committee }\end{array}$ \\
\hline
\end{tabular}


Table 3 shows the correlation between the study variables in the Jordanian public shareholding companies. Based on the table, there is no correlation between $80 \%$ of the study variables, indicating that there is no high correlation between the study variables and the size of the audit committee and board of directors.

\subsection{Multicollinearity test: Variance inflationary factor (VIF)}

To confirm the results of the Pearson correlation matrix in the previous table, a VIF test was used to test for the existence of an overlap between independent variables, as shown in Table 4.

Table 4. Multicollinearity Test

\begin{tabular}{|l|l|}
\hline Variables & VIF \\
\hline Family ownership ratio & 1.011 \\
\hline Board size & $1.088 \mathrm{~s}$ \\
\hline Audit committee size & 1.077 \\
\hline
\end{tabular}

The table shows the variables of the independent study and the VIF values for each. As shown in the table, all the variables have VIF values lower than 5 , confirming that there is no overlap between independent variables.

\subsection{Testing of the hypotheses of the study}

Main hypothesis: "The application of governance rules has no impact on the voluntary disclosure level of public shareholding companies listed with the ASE."

To prove or negate this hypothesis, its subhypotheses were tested. The following is the presentation of the results of the hypothesis test and their comparison with the results of previous studies. The $t$ and Sig. values were considered in accepting or rejecting the hypotheses. If the Sig. value is 0.05 , the null hypothesis is rejected, and the alternative hypothesis is accepted. It also indicates the ratio to which each independent variable is interpreted in the dependent variable, depending on the value of the Adjusted $R$ Square parameter.

First subhypothesis (Ho1): The family ownership ratio has no statistically significant effect on the voluntary disclosure level of public shareholding companies listed with the ASE.

Table 5. Results of the Simple Regression Test of the Family Property Ratio at the Voluntary Disclosure Level

\begin{tabular}{|c|l|l|l|l|l|}
\hline Sig. & t-Statistics & $\begin{array}{c}t \text { - Distribution } \\
\text { Table }\end{array}$ & Coefficients & Constant B & $\begin{array}{c}\text { Ownership } \\
\text { Family Ratio } \\
\text { B }\end{array}$ \\
\hline 0.941 & 0.074 & 1.982 & 0.007 & 19.434 & 0.226 \\
\hline \multicolumn{2}{|c|}{ Adjusted R Square } & -0.009 \\
\hline \multicolumn{2}{|l}{ Model F Test } \\
\hline
\end{tabular}


Table 5 presents the results of the simple regression analysis of the independent variable (family ownership ratio) and its effect on the dependent variable (the optional disclosure level). The results showed that the calculated $t$ value is less than the tabular value. According to the rule of decision that provides for the acceptance of hypothesis Ho if the calculated value is less than the tabular value and the Sig. value is greater than 0.05 , the family ownership ratio does not affect the voluntary disclosure level. Therefore, the first nihilistic hypothesis - Ownership Family Ratio has no statistically significant effect on the optional disclosure level of the public shareholding companies listed with the ASE-is verified. Moreover, the researcher believes that the reason for this is that the family ownership ratio is the number of family members within the board of directors, which is mainly responsible for the voluntary disclosure process, and not the percentage of ownership.

Second subhypothesis: "The size of the board of directors has no statistically significant effect on the level of voluntary disclosure of public shareholding companies listed with the ASE."

Table 6. Results of the Simple Regression Test of the Size of the Board of Directors at the of Voluntary Disclosure Level

\begin{tabular}{|c|l|l|l|l|l|}
\hline Sig. & t-Statistics & $\begin{array}{c}\text { t- Distribution } \\
\text { Table }\end{array}$ & Coefficients & Constant B & $\begin{array}{c}\text { Board Size Ratio } \\
\text { B }\end{array}$ \\
\hline 0.001 & 4.402 & 1.982 & 0.390 & 15.804 & 0.430 \\
\hline \multicolumn{2}{|c|}{ Adjusted R Square 0.144} \\
\hline \multicolumn{2}{|c|}{19.381} \\
\hline
\end{tabular}

Table 6 presents the results of the simple regression analysis of the independent variable (size of the board of directors) and its effect on the dependent variable (optional disclosure level). The results showed that the calculated $t$ value is greater than its tabular value. According to the rule of decision stating that hypothesis $\mathrm{H}$ is rejected if the calculated value is greater than the $t$ value and the Sig. value is less than 0.05 , the size of the board of directors affects the voluntary disclosure level. The alternative hypothesis is that the size of the council has a statistically significant effect on the voluntary disclosure level of the public shareholding companies in the ASE. It should be noted that during the review of this table, the adjusted $\mathrm{R}$ square coefficient reached 0.144 , which means that the optional disclosure is explained by the percentage change in the size of the board of directors. This is because the board of directors is the main authority in public shareholding companies when it comes to the process of determining the voluntary disclosure level and decision-making. This result supports the findings of the researcher in the first subhypothesis.

Based on the results of the simple regression analysis above, the linear regression equation for optional disclosure and the size of the board of directors have been prepared to predict the optional disclosure as follows:

$Y=15.804+(0.430 \times X 1)+e$ 
Where:

Y: Optional disclosure and

$\mathrm{X} 1$ : Size of the board.

Third subhypothesis: "The size of the audit committee has no statistically significant effect on the voluntary disclosure level of public shareholding companies listed with the ASE."

Table 7. Results of the Simple Regression Test of the Audit Committee Size at the Optional Disclosure Level

\begin{tabular}{|c|l|l|l|l|l|}
\hline Sig. & \multicolumn{1}{|c|}{$\begin{array}{c}\boldsymbol{t} \text { - } \\
\text { Statistics }\end{array}$} & $\begin{array}{c}\text { t- } \\
\text { Distribution } \\
\text { Table }\end{array}$ & Coefficients & Constant B & $\begin{array}{c}\text { Audit B ratio } \\
\text { B }\end{array}$ \\
\hline 0.607 & 0.516 & 1.982 & 0.050 & 19.353 & 0.103 \\
\hline \multicolumn{5}{|c|}{ Adjusted R Square -0.007} \\
\hline \multicolumn{2}{|c|}{0.267} \\
\hline
\end{tabular}

Table 7 presents the results of the simple regression analysis of the independent variable (size of the audit committee) and its effect on the dependent variable (the optional disclosure level). The results showed that the calculated $t$ value is less than the tabular value. According to the rule of decision that provides for the acceptance of hypothesis Ho if the calculated value is less than the tabular value and the Sig. value is greater than 0.05 , the audit committee size does not affect the voluntary disclosure level. Therefore, the third subhypothesis - the audit committee size has no statistically significant effect on the level of the audit committee-is verified. The reason for this is that the audit committee usually submits its recommendations to the board of directors and determines the voluntary disclosure level. Ultimately, however, the decision lies with the board of directors. This result supports the findings of the researcher in the two previous hypotheses.

\subsection{Multiple regression test results}

For the purpose of proving the previously obtained results, as well as the order of influence of some factors on optional disclosure, the multiple regression test was performed for all independent variables, as shown in Table 8.

\subsubsection{Multiple regression analysis results of the study variables}

Model Summary

\begin{tabular}{|l|l|l|l|l|}
\hline Model & \multicolumn{1}{|c|}{$\mathbf{R}$} & R Square & \multicolumn{1}{|c|}{$\begin{array}{c}\text { Adjusted R } \\
\text { Square }\end{array}$} & $\begin{array}{c}\text { Standard. Error of } \\
\text { the Estimate }\end{array}$ \\
\hline 1 & $0.396^{\mathrm{a}}$ & 0.157 & 0.133 & 3.10451 \\
\hline
\end{tabular}

a. Predictors: (Constant) Auditing, own, board

ANOVA $^{\text {b }}$ 
Studies in Business and Economics no. 14(1)/2019

\begin{tabular}{|c|c|c|c|c|c|c|}
\hline & Model & Sum of Squares & df & Mean Square & $\mathbf{F}$ & Sig. \\
\hline \multirow[t]{3}{*}{1} & Regression & 189.550 & 3 & 63.183 & 6.556 & $0.001^{a}$ \\
\hline & Residual & 1021.623 & 106 & 9.638 & & \\
\hline & Total & 1211.173 & 109 & & & \\
\hline
\end{tabular}

a. Predictors: (Constant) Auditing, own, board

b. Dependent variable: Dep

\section{Coefficients $^{\mathrm{a}}$}

\begin{tabular}{|c|c|c|c|c|c|c|}
\hline & \multirow[b]{2}{*}{ Model } & \multicolumn{2}{|c|}{ Unstandardized Coefficients } & \multirow{2}{*}{\begin{tabular}{|l}
$\begin{array}{c}\text { Standardized } \\
\text { Coefficients }\end{array}$ \\
Beta
\end{tabular}} & \multirow[b]{2}{*}{$t$} & \multirow[b]{2}{*}{ Sig. } \\
\hline & & $B$ & Standard Error & & & \\
\hline \multirow[t]{4}{*}{1} & (Constant) & 15.789 & 0.888 & & 17.787 & 0.001 \\
\hline & Own & $-1.079-$ & 2.857 & $-0.034-$ & $-0.378-$ & 0.706 \\
\hline & Board & 0.451 & 0.103 & 0.409 & 4.399 & 0.001 \\
\hline & Auditing & $-0.122-$ & 0.193 & $-0.059-$ & $-0.633-$ & 0.528 \\
\hline
\end{tabular}

a. Dependent variable: dep

Based on the discussion of the subhypotheses and Table 7 where Sig. 0.001 was reached, the main null hypothesis was rejected, and the alternative hypothesis was accepted. This means that there is an effect on the application of the rules of governance (family ownership ratio and size of the board of directors), combined with the voluntary disclosure level of the public shareholding companies. It should also be noted that the results of the multiple regression analysis showed that the adjusted $R$ square coefficient was 0.133 . This means that the application of the overall rules of governance (family ownership ratio and size of the board of directors) is explained by this percentage change in the level of the IF Optional. The researcher believes that this result is in line with the study of Zaheer (2013) on the Pakistani financial market, which found that the size of the board of directors influence the level of disclosure of financial statements. Using the data in Table 5, the linear regression equation for all study variables can be prepared as follows:

$\mathrm{Y}=15.789+(-1.079 \times \mathrm{X} 1)+(0.451 \times \mathrm{X} 2)+(-0.122 \times \mathrm{X} 3)+\mathrm{e}$

Where:

Y: Optional disclosure level;

$\mathrm{X} 1$ : Family ownership ratio;

X2: Size of the board of directors;

X3: Size of the audit committee; and

E: Error ratio.

To compare and clarify the differences between the sectors included in the study society, a table was prepared to show the ranking of the four sectors (banking, insurance, services, and industrial sectors) according to the degree of influence of the independent factors (family ownership ratio, size of the board of directors, and size of the audit committee) on optional disclosure: 
Table 9. Order of Effects by Sector

\begin{tabular}{|c|c|c|c|}
\hline Ranking & Sector & Sig. & Adjusted R Square \\
\hline $\mathbf{1}$ & Industrial & 0.002 & 0.308 \\
\hline $\mathbf{2}$ & Banking & 0.101 & 0.139 \\
\hline $\mathbf{3}$ & Services & 0.151 & 0.060 \\
\hline $\mathbf{4}$ & Insurance & -- & --- \\
\hline
\end{tabular}

Table 9 shows the effect of the application of the overall rules of governance combined with the voluntary disclosure level and the classification by sectors in the Jordanian public shareholding companies, that is, from the most to the least influential. Based on the table, the only sector where the impact of the application of the rules of governance is combined with the voluntary disclosure level is at Sig. $<0.05$, the industrial sector, which is followed by the banking and services sectors with Sig. values greater than 0.05. As for the insurance sector, according to the multiple regression test, there is no variation in the answers; however, the application of the governance rules also has no effect on the voluntary disclosure level in the insurance sector.

The study considers that the absence of an effect on the independent variables combined with the optional disclosure in the banking and insurance sectors may be due to the fact that both sectors are governed by instructions from several quarters. The banking sector is governed by the instructions of the Central Bank and the Securities Commission, as well as the Insurance and Securities Authority. In addition, both sectors (banking and insurance) are also governed by their board of directors in determining the voluntary disclosure level. Thus, it is possible to say that there are many factors that govern the voluntary disclosure level in these sectors. There is a body that complies with the requirements of voluntary disclosure other than the JSC. It is binding on all sectors. Therefore, the industry sector is only governed by the board of directors and the Securities Authority. As for the services sector, there are special regulators that govern the disclosure process-communications and other entities that govern the disclosure process in addition to the Securities Commission and the board of directors of the companies.

\section{Conclusions}

In the light of the statistical analysis results, this study could shape the findings as the public shareholding companies listed with ASE omitted the disclosure of the minutes of the ordinary and extraordinary meetings of the Authority in their annual financial statements. In addition, there is a lack of disclosures regarding future forecasts of the financial statements of the public shareholding companies listed with the ASE. The study revealed that family ownership ratio does not have a statistically significant effect on the voluntary disclosure level of the public shareholding companies listed with ASE. In terms of the size of the board of directors affects the voluntary disclosure level. Accordingly, the study found that size of the board of directors has a statistically significant effect on the 
voluntary disclosure level of the public shareholding companies listed with the ASE. Regarding the size of the audit committee the study indicated that the size of the audit committee has no statistically significant effect on the voluntary disclosure level of public shareholding companies listed with the ASE. Finally, the results showed that there is an effect on the application of the rules of governance combined on the level of voluntary disclosure level. Therefore, the main null hypothesis and the alternative hypothesis have been rejected. This means that the application of the rules of governance (family ownership ratio, size of the board of directors, and size of the audit committee) affects the voluntary disclosure level of public shareholding companies.

\section{Recommendations}

1. The researcher recommends increasing the interest in disclosing the future prediction of the public shareholding companies because it is considered by the beneficiaries of the financial statements as an important disclosure.

2. The researcher also recommends increasing the volume of optional disclosure items in the financial statements of companies listed with the ASE to provide the necessary information that may affect the decisions of investors and beneficiaries of the financial statements.

3. The rules of governance of public shareholding companies should be applied, and there must be a supervisory committee from the Securities and Exchange Commission to urge companies to apply these rules.

4. A study on a sample of other public shareholding companies listed with the ASE should be conducted.

5. A study should be conducted on other categories of dependent variables in view of the importance of the application of the rules of governance to measure their impact on the financial performance of public shareholding companies.

\section{References}

Abed Al-Nasser Abdallah, Ahmad K. Ismail (2017) CG practices, ownership structure, and corporate performance in the GCC countries (2017) Journal of International Financial Markets, Institutions and Money, Volume 46, January 2017, Pages 98-115.

Abubakar M. Dembo, Syamarlah Rasaratnam (2014) Corporate Governance and Disclosure in Nigeria: An Empirical Study, Procedia - Social and Behavioral Sciences, Volume 164, 31 December 2014, Pages 161-171.

Amer Alhazaimeh, Ravindran Palaniappan, Mahmoud Almsafir (2014) The Impact of Corporate Governance and Ownership Structure on Voluntary Disclosure in Annual Reports among Listed Jordanian Companies, Procedia - Social and Behavioral Sciences, Volume 129, 2014, Pages 341-348, ISSN 1877-0428, http://dx.doi.org/10.1016/j.sbspro.2014.03.686.

Ana Gisbert, Begoña Navallas (2013) The association between voluntary disclosure and Corporate Governance in the presence of severe agency conflicts, Advances in Accounting, Volume 29, Issue 2, 2013, Pages 286-298, ISSN 0882-6110, http://dx.doi.org/10.1016/j.adiac.2013.07.001. 
Caspar Rose (2016) Firm performance and comply or explain disclosure in corporate governance, European Management Journal, Volume 34, Issue 3, June 2016, Pages 202-222.

Christopher Hodgdon, Susan B. Hughes (2016) The effect of corporate governance, auditor choice and global activities on EU company disclosures of estimates and judgments, Journal of International Accounting, Auditing and Taxation, Volume 26, 2016, Pages 28-46.

Eduardo Ortas, Igor Álvarez, Jacques Jaussaud, Ainhoa Garayar ( 2015) The impact of institutional and social context on corporate environmental, social and governance performance of companies committed to voluntary corporate social responsibility initiatives, Journal of Cleaner Production, Volume 108, Part A, 1 December 2015, Pages 673-684 .

Ehtazaz Javaid Lone, Amjad Ali, Imran Khan, (2016) " Corporate Governance and corporate social responsibility disclosure: evidence from Pakistan", Corporate Governance: The International Journal of Business in Society, Vol. 16 Issue: 5, pp.785-797, https://doi.org/10.1108/CG-052016-0100.

Faten Lakhal, (2005) "Voluntary Earnings Disclosures and Corporate Governance: Evidence from France", Review of Accounting and Finance, Vol. 4 Issue: 3, pp.64-85, https://doi.org/10.1108/eb043431.

Grigoris Giannarakis, (2014) " Corporate Governance and financial characteristic effects on the extent of corporate social responsibility disclosure", Social Responsibility Journal, Vol. 10 Issue: 4, pp.569-590, https://doi.org/10.1108/SRJ-02-2013-0008.

Guadalupe del Carmen Briano-Turrent, Lázaro Rodríguez-Ariza (2016) Corporate Governance ratings on listed companies: An institutional perspective in Latin America, European Journal of Management and Business Economics, Volume 25, Issue 2, 8 May 2016, Pages 63-75.

Jordan Schoenfeld (2017) The effect of voluntary disclosure on stock liquidity: New evidence from index funds, Journal of Accounting and Economics, Volume 63, Issue 1, February 2017, Pages 51-74.

Khaled Samaha, Khaled Dahawy, Khaled Hussainey, Pamela Stapleton (2012) The extent of Corporate Governance disclosure and its determinants in a developing market: The case of Egypt, Advances in Accounting, Volume 28, Issue 1, June 2012, Pages 168-178.

Laura Cabeza-García, María Sacristán-Navarro, Silvia Gómez-Ansón ( 2017) Family involvement and corporate social responsibility disclosure, Journal of Family Business Strategy, Volume 8, Issue 2, June 2017, Pages 109-122 .

Lili Dai, Renhui Fu, Jun-Koo Kang, Inmoo Lee (2016) Corporate Governance and the profitability of insider trading , Journal of Corporate Finance, Volume 40, October 2016, Pages 235-253.

M. Akhtaruddin, Hasnah Haron, (2010) "Board ownership, audit committees' effectiveness, and corporate voluntary disclosures", Asian Review of Accounting, Vol. 18 Issue: 3, pp.245-259, https://doi.org/10.1108/13217341011089649.

M. Rosario Babío Arcay, M. Flora Muiño Vázquez (2005) Corporate Characteristics, Governance Rules and the Extent of Voluntary Disclosure in Spain, Advances in Accounting, Volume 21, 2005, Pages 299-331 ， M. Rosario Babío Arcay, M. Flora Muiño Vázquez.

Melsa Ararat, Bernard S. Black, B. Burcin Yurtoglu (2017) The effect of Corporate Governance on firm value and profitability: Time-series evidence from Turkey, Emerging Markets Review, Volume 30, March 2017, Pages 113-132.

Mishari M. Alfraih, Abdullah M. Almutawa, (2017) "Voluntary disclosure and corporate governance: empirical evidence from Kuwait", International Journal of Law and Management, Vol. 59 Issue: 2, pp.217-236, https://doi.org/10.1108/IJLMA-10-2015-0052.

Mohamed H. Elmagrhi, Collins G. Ntim, Yan Wang, (2016) "Antecedents of voluntary Corporate Governance disclosure: a post-2007/08 financial crisis evidence from the influential UK Combined Code", Corporate Governance, Vol. 16 Issue: 3, pp.507-538, https://doi.org/10.1108/CG-01-2016-0006. 
Murya Habbash, (2016) " Corporate Governance and corporate social responsibility disclosure: evidence from Saudi Arabia", Social Responsibility Journal, Vol. 12 Issue: 4, pp.740-754, https://doi.org/10.1108/SRJ-07-2015-0088.

Poh-Ling Ho, Grantley Taylor, (2013) " Corporate Governance and different types of voluntary disclosure: Evidence from Malaysian listed firms", Pacific Accounting Review, Vol. 25 Issue: 1, pp.4-29, https://doi.org/10.1108/01140581311318940.

Rohana Othman, Ili Farhana Ishak, Siti Maznah Mohd Arif, Nooraslinda Abdul Aris (2014) Influence of Audit Committee Characteristics on Voluntary Ethics Disclosure, Procedia - Social and Behavioral Sciences, Volume 145, 25 August 2014, Pages 330-342.

Ronald F. Premuroso, Somnath Bhattacharya (2008) Do early and voluntary filers of financial information in XBRL format signal superior Corporate Governance and operating performance?, International Journal of Accounting Information Systems, Volume 9, Issue 1, March 2008, Pages 1-20.

Simon S.M Ho, Kar Shun Wong (2001) A study of the relationship between Corporate Governance structures and the extent of voluntary disclosure, Journal of International Accounting, Auditing and Taxation, Volume 10, Issue 2, Summer 2001, Pages 139-156.

Syed Abdulla Al Mamun, Hasnah Kamardin (2014) Corporate Voluntary Disclosure Practices of Banks in Bangladesh, Procedia - Social and Behavioral Sciences, Volume 164, 31 December 2014, Pages 258-263.

Wan Ainul Asyiqin Wan Mohd Razali, Roshayani Arshad (2014) Disclosure of Corporate Governance Structure and the Likelihood of Fraudulent Financial Reporting, Procedia - Social and Behavioral Sciences, Volume 145, 25 August 2014, Pages 243-253.

Wan Amalina Wan Abdullah, Majella Percy, Jenny Stewart (2015), Journal of Contemporary Accounting \& Economics, Volume 11, Issue 3, December 2015, Pages 262-279.

Xiang Liu, Chen Zhang (2017), corporate governance, social responsibility information disclosure, and enterprise value in China, Journal of Cleaner Production, Volume 142, Part 2, 20 January 2017, Pages 1075-1084.

Xiao Huafang, Yuan Jianguo, (2007) "Ownership structure, board composition and corporate voluntary disclosure: Evidence from listed companies in China", Managerial Auditing Journal, Vol. 22 Issue: 6, pp.604-619, https://doi.org/10.1108/02686900710759406.

Xu-dong Ji, Wei Lu, Wen Qu (2015) Determinants and economic consequences of voluntary disclosure of internal control weaknesses in China, Journal of Contemporary Accounting \& Economics, Volume 11, Issue 1, April 2015, Pages 1-17.

Yan Qiu, Amama Shaukat, Rajesh Tharyan (2016) Environmental and social disclosures: Link with corporate financial performance, The British Accounting Review, Volume 48, Issue 1, March 2016, Pages 102-116.

Yu Cong, Martin Freedman, Corporate Governance and environmental performance and disclosures, Advances in Accounting, Volume 27, Issue 2, 2011, Pages 223-232, ISSN 0882-6110, http://dx.doi.org/10.1016/j.adiac.2011.05.005. 